4) and its literary affinity.

9) A. Wifstrand: "The Homily of Melito on the Passion," Vig. Chri. ii, 1948, p. 201-223.

10) It is difficult to count the number, because there are $340 \mathrm{di}$ fferent reading between the texts, and because there are still lacunae to be filled and reconstructed.

11) Peri Pascha, III, IV, XXXIX-XLV.

12) ibid: VII.

13) Justin: Dialogue with Trypho, XL.

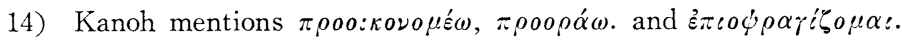
as the words which can be taken typologically. Daniélou adds

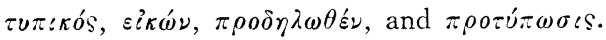

15) Ante-Nicene Fathers, Vol. VIII, p. 757. 


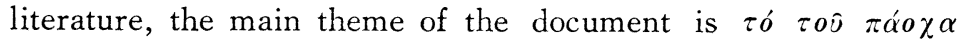
$\mu \nu \sigma \tau \eta \dot{p} \rho \iota \boldsymbol{\nu}$ for which Melito wrote this, making use of all sorts of literary forms. The Jewish Passover was celebrated among the families, while Christian Pascha (containing Easter) celebration was held at the public worship of churches. We can conclude that the Haggadah element underlying this document is not in its liturgical forms, but in its homiletics, the way of applying the exegesis to the up-to-date problems.

We can not deny its liturgical character, from repeated doxologies and from the confession of faith as a sort of conclusion of this homily. $\sigma \phi \rho \sigma \gamma^{\prime}{ }^{\prime} \omega$ is also a key word which was closely connected with the baptismal liturgy in the early church.

Then our conclusion is that this document is a Paschal homily which was read at the time of Christian Paschal service from Passion week to Easter Sunday, including baptism and communion.

\section{Notes}

1) Ante-Nicene Fathers, Vol. VIII, p. 757.

2) It is arranged as follows: $70,71,72,75,80 ; 1 \mathrm{a}, 7 \mathrm{~b}, 80 ; 8,81,82$, $93 ; 3,4,8,5,10,11,13,95,96,98,99,100,104$.

3) H. Chadwick: "A Latin Epitome of Melito's Homily on the Passion," Journal of Ecclesiastical Studies, 1960.

4) Masahiro Kanoh: "Sarudesu no Shikyo Meliton no Sugikoshi no Kohitsuji ni tsuite," Seisho to Shingaku, 1963 M. Kanoh: Sugikoshi Densho no Kenkyu, 1971.

5) G.F. Hawthorne: “A New English Translation of Melito's Paschal Homily," Current Issues in Biblical and Patristic Interpretation, 1975 Eerdmans, Michigan.

6) Eusebius: The History of the Church, V. 24.

7) K.W. Noaks: "Melito of Sardis and the Jews," Studia Patristica, XIII, p. 244-249.

8) M. Kanoh discusses the question in four points: 1) its theme, 2) its similarity of its contents, 3) with seven comparisons. 
The mystery of our Lord was foretold in the Old Testament in various ways; in the murdered Abel, in the sacrificed Isaac, in the exiled Jacob, and in the sold Joseph. This is the expression Melito uses repeatedly in LIX and in LXIX. Also we find it in the fragment of Melito, named 'on Faith'. ${ }^{15}$ )

Melito says, "the mystery of the passover has been completed in the body of the Lord." (LVI) All the Scripture gives witness to the mystery of the Lord. (LIX-LXV) The explanation of the mystery leads the partakers of the mystery to the full confession of faith, which appeared at the end of the homily. (C-CV) Here Melito's typology is related to the liturgy, which was the life of the Church. For the reason we call it the eccesiological typology.

\section{5) Conclusion}

Our first question was whether Melito stands on the side of Greek culture or under the tradition of Jewish religion. It can be admitted that the one third of Peri Pascha is filled with reproach against the Jews. His accusation is, i) because Israel has paid him back with ingratitude (XC), ii) because they killed the Lord at the time of the great feast (XCII), and because they killed him in the midst of Jerusalem (XCIV). Whom was this document addressed to ? Was it not the people

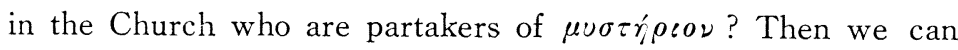
understand that Melito's homily leads the Christian to repentance and gives them warning not to go away from the grace of Jesus Christ, the true lamb of the Passover. At the time when the Christian doctrines were on their way to formation, Melito was one of those who struggled with living in Asia Minor under the influence of Greek culture and Jewish religion.

The second question was concerning the literary form of Peri Pascha. Admitting that there is influence from the Jewish 
suffering of our Lord with His salvation and His redemption was foretold in the type, that is, the sheep of the Passover.

\section{4) Ecclesiological Typology}

Melito's typology is deepened first, in the words other than

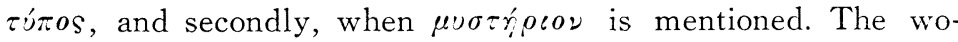

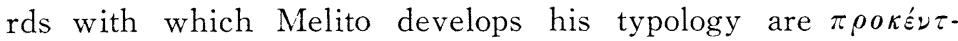

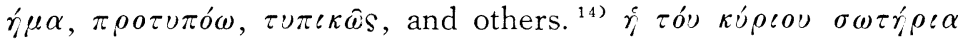
$\kappa \alpha i \dot{\alpha} \lambda \dot{\gamma} \theta \varepsilon \iota \alpha$ हैं $\tau \hat{\varphi} \quad \lambda \alpha \hat{\varphi} \pi \rho o \varepsilon \tau \cup \pi \omega \theta \eta$. (XXXIX) “The salvation and its realization were prefigured in the "whole history of the people in the Old Testament. Its history was the type of the Church, the new Israel. Melito understands God the ruler of the history of the world. The suffering of Christ, and the salvation of the people of God were pre-planned long in advance, (LVII) and are now brought to perfection in Jesus Christ. Melito is said to be the first theologian who definitely states the salvation history.

Secondly, in the Peri Pascha of Melito the crucial word to

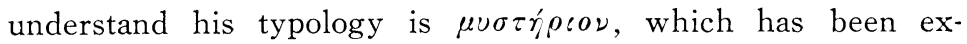
plained again and again, and which is to be listened to. (I, XX XIV)

He speaks of the mystery of the Passover which is inexpressible and extraordinary. This is the theme of this homily. "The mystery of the Passover is new and old, eternal and temporal, corruptible and incorruptible, mortal and immortal " (II) The corruptibility and mortality exist along with the incorruptibility and the immortality. That is the significance of sacraments.

The people of Israel was sealed with the blood of the lamb; for the sake of the seal, those who partake the mystery will be saved. (LXVII) Egypt, who was neither initiated into the mystery, nor sealed by the blood, was destroyed. Whenever the Passover is celebrated, they remembered the grace of God who delivered them from the land of bondage. 
smitted its resemblance to that which is by nature true." (XXXIIV)

Both the people and the type had values, before the reality appeared. But when it came, they lost their significance. It should be noticed that Melito distinguishes the type and the poeple from the law and the parables. This means for Melito the history which was led by God, and the word which was told through the Law, do not belong to the same dimension.

ii) The importance of $\alpha \dot{\alpha} \eta^{\prime} \theta \varepsilon<\alpha$ (reality) for Melito must be

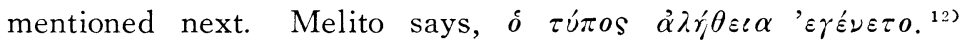
$\dot{\alpha} \lambda \dot{r} \theta \varepsilon \iota \alpha$ means the reality of Jesus who is by nature God and man. The type is like shadow which disappears when the real being comes into existence. The $\dot{\alpha} \lambda \dot{\eta} \theta \varepsilon \iota \alpha$ is $\dot{\alpha} \nu \tau i \tau u \pi o s$ of the Exodus type. It includes everything which is written in the Gospel.

iii) The other three cases refers to the type of the Lord and His sufferings, of which more should be added in the next chapter.

\section{3) The Lamb of Passover}

It is the main theme of Melito that the lamb of Passover prefigures Christ in its sacrifice, in its blood and in its deliverance from the bondage of sins. Following Justin, ${ }^{13)}$ Melito has $\dot{\omega}$ ¿ $\dot{\alpha} \mu \nu$ ós typology. "The speechless lamb (IV, XLIV, LXXI) was once valuable, but now it is without value because of the blameless Son." (XLIV)

In the sacrifice of the sheep, in the death of the sheep and in the blood of the sheep, the suffering servant is referred to. (XXX-XXXIII) "Israel was being protected by the sacrifice of the sheep and truly was being illumined by its blood...; for the death of the sheep was found to be a rampart for the people." $(\mathrm{XXXX})$ It is the mystery of the Lord whose type the sheep was. The destroyer was turned away when he saw the type of the Lord in the sacrifice of the sheep at the Passover. The 
preparations for the crucifixion, getting ready nails, false witnesses, cords, scourges, vinigar, ...." ${ }^{\text {?) }}$

Therefore our first question is Melito's position as a Christian, taking typological exegesis into consideration.

Our second question is, first raised by F.L. Cross and followed by a Japanese theologian, M. Kanoh, if this document is a kind of Christian Passover-Haggadah. L. W. Barnard says that this belongs to the group of so-called Paschal Homily, which starts from 1 Peter, succeeded by Barnabas, Melito, Hippolytus and so on. Kanoh points out several parallels between the Jewish Haggadah and Melito's homily. ${ }^{8)}$ There is another view raised by Wifstrand that this is a document of Greek rhetorics. ${ }^{92}$ Our task is, therefore, to find out what kind of document Melito's Peri Pascha is.

\section{2) The Use of $\tau \dot{x} \pi o s$ in Melito}

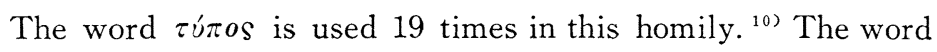
$\tau$ úxos can be taken in several ways, but in Melito it is explicit that it means the type. Sixteen times out of nineteen, Melito explains the meaning of the type, and that becomes his hermeneutical principles. Three things can be mentioned.

i) Melito understands that types are characterized with its finiteness. Melito says that the type is within the limit of time and space. When the time is fulfilled, the type loses its meaning and is to be destroyed. Melito recognizes the difference of time in quality between O. T. and N. T. One is old because it belongs to the Law, the other is new, for it belongs to the Gospel. By saying that the type is temporal, and the grace is eternal, he establishes the expository principles of the Exodus events.

"So whenever the thing arises for which the model was made, then that which carried the image of that future thing is destroyed as no longer of use, since it has tran- 


\title{
Typology in Melito's PERI PASCHA
}

\author{
Kikuko Yamamoto
}

Melito, an excellent leader in Asia Minor, has been noticed since 1940, when Bonner Text of his Peri Pascha was published. A number of texts and translations followed Bonner. Thanks to these publications, now we can read the wonderful document in the second century in almost restored form. In this short paper our concern is on Melito's theology with special reference to his typology.

By 1940, only fragments were known in Coptics, Syrian, and Greek. For example, No. 5 of Melito's writing') was handed down without any sufficient explanation, but now we know that it is an excerpt from LXX to CIV of Peri Pascha of Melito. ${ }^{2)}$ H. Chadwick's thorough examination brought to light that the Latin epitome, which survived under the names of other authors, ${ }^{3)}$ is also an excerpt from Peri Pascha of Melito. To our advantage Masahiro Kanoh elaborated on text criticism, and Greek text with his Japanese translation came out on Seisho to Shingaku, 1963. His renewed translation was published in 1971. ") For English readers, we can name G. Hawthorn's translation on Current Issues in Biblical and Patristic Interpretation. ${ }^{5)}$

Melito is known one of the Quartodecimen, who "kept the fourteenth day of Nisan as the beginning of the Pascal festival, ${ }^{, 6}$ ) no matter what day of the week it is. From this fact Melito is said to be closer to the Jewish tradition than to Greek culture. But K. W. Noaks has an opposite opinion that Melito was strongly against the Jews, saying:

"According to Melito it was the Jews who made all the 